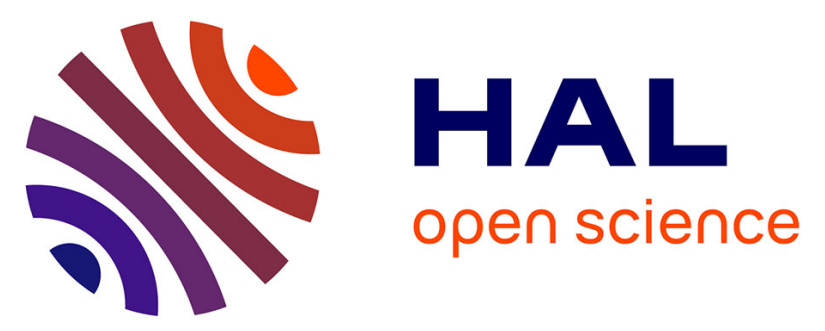

\title{
Complex formation between manganese(II), cobalt(II), nickel(II), copper(II) and a series of new ligands derived from N,N'-O-phenylenebis(salicylideneimine)
}

Sabrina Belaid, Safia Djebbar, Ouassini Benali-Baitich, Mustayeen A. Khan, Gilles Bouet

\section{To cite this version:}

Sabrina Belaid, Safia Djebbar, Ouassini Benali-Baitich, Mustayeen A. Khan, Gilles Bouet. Complex formation between manganese(II), cobalt(II), nickel(II), copper(II) and a series of new ligands derived from N,N'-O-phenylenebis(salicylideneimine). Comptes Rendus. Chimie, 2006, 10, pp.568 - 572. 10.1016/j.crci.2006.09.012 . hal-03232162

\section{HAL Id: hal-03232162 \\ https://univ-angers.hal.science/hal-03232162}

Submitted on 31 May 2021

HAL is a multi-disciplinary open access archive for the deposit and dissemination of scientific research documents, whether they are published or not. The documents may come from teaching and research institutions in France or abroad, or from public or private research centers.
L'archive ouverte pluridisciplinaire HAL, est destinée au dépôt et à la diffusion de documents scientifiques de niveau recherche, publiés ou non, émanant des établissements d'enseignement et de recherche français ou étrangers, des laboratoires publics ou privés. 
Account / Revue

\title{
Complex formation between manganese(II), cobalt(II), nickel(II), copper(II) and a series of new ligands derived from $N, N^{\prime}-O$-phenylenebis(salicylideneimine)
}

\author{
Sabrina Belaid ${ }^{\text {a }}$, Safia Djebbar ${ }^{\text {a }}$, Ouassini Benali-Baitich ${ }^{\text {a,* }}$, \\ Mustayeen Khan ${ }^{\mathrm{b}}$, Gilles Bouet ${ }^{\mathrm{b}}$ \\ ${ }^{a}$ Laboratoire d'hydrométallurgie et chimie inorganique moléculaire, USTHB, BP 32 El Alia, 16111 Bab-Ezzouar, Alger, Algeria \\ ${ }^{\mathrm{b}}$ Laboratoire SONAS, Chimie de coordination, faculté de pharmacie, 16, bd Daviers, 49045 Angers cedex 01, France
}

Received 22 May 2006; accepted after revision 15 September 2006

Available online 20 December 2006

\begin{abstract}
A series of new ligands derived from $N, N^{\prime}$-O-phenylenebis(salicylideneimine) have been synthesized and characterized by spectrometric methods. Their protonation constants and the stability constants of their complexes with $\mathrm{Mn}^{2+}, \mathrm{Co}^{2+}, \mathrm{Ni}^{2+}$ et $\mathrm{Cu}^{2+}$ have been determined by potentiometric methods in a water-ethanol $(90: 10 \mathrm{v} / \mathrm{v})$ mixture at a $0.2 \mathrm{~mol}^{-1}$ ionic strength $(\mathrm{NaCl})$ and at $25.0 \pm 0.1^{\circ} \mathrm{C}$. The Sirko program was used to determine the protonation constants as well as the binding constants of both species $[\mathrm{M}(\mathrm{HL})]^{+}$and $[\mathrm{ML}]$. The stability order obtained is in agreement with Irving-Williams series. To cite this article: S. Belaid et al., C. R. Chimie 10 (2007).

(C) 2006 Académie des sciences. Published by Elsevier Masson SAS. All rights reserved.

\section{Résumé}

Une série de nouveaux ligands dérivés de la $N, N^{\prime}$-O-phenylenebis(salicylidèneimine)a été synthétisée et caractérisée par les méthodes spectrométriques conventionnelles. L'étude de la complexation des ions métalliques $\mathrm{Mn}^{2+}, \mathrm{Co}^{2+}, \mathrm{Ni}^{2+}$ et $\mathrm{Cu}^{2+}$, par ces ligands, a été effectuée par pH-métrie en milieu eau-éthanol $90: 10$ (vol./vol.) à $25^{\circ} \mathrm{C} \pm 0.1$ et à force ionique constante $0,2 \mathrm{M}$ en milieu $\mathrm{NaCl}$. Les constantes de protonation des ligands et les constantes de stabilités des deux espèces $[\mathrm{M}(\mathrm{HL})]^{+}$et $[\mathrm{ML}]$ ont été déterminées à l'aide du programme Sirko. L'ordre de stabilité obtenu pour les complexes est en accord avec la série d'Irving et Williams. Pour citer cet article : S. Belaid et al., C. R. Chimie 10 (2007).
\end{abstract}

(C) 2006 Académie des sciences. Published by Elsevier Masson SAS. All rights reserved.

Keywords: Schiff base; Reduction; Potentiometry; Stability constants

Mots-clés : Base de Schiff ; Réduction ; Potentiométrie ; Constantes de stabilités

\footnotetext{
* Corresponding author.

E-mail address: benali-baitich@netcourrier.com (O. Benali-Baitich).
} 


\section{Introduction}

Schiff bases constitute an interesting class of chelating agents. Due to their preparative accessibility, diversity and structure variability, they are capable of coordinating metal ions, giving complexes which exhibit wide applications in biological systems and industrial uses [1-3].

Schiff bases derived from ortho-phenylenediamine are of particular interest because of the proximity of the nitrogen atoms, which permits their simultaneous coordination to the same metal cation, leading mainly to stable monomer species [4-6].

However, these Schiff bases can be reduced to the corresponding amine derivatives, which have a higher stability because they are more flexible and not constrained to remaining planar [7-9], and they do not suffer the hydrolytic processes encountered with Schiff base analogues [10].

Our interest in the chemistry of reduced Schiff bases has also stemmed from previous results about antitumor activities of complexes of $\mathrm{Cu}(\mathrm{II})$ with a reduced Schiff base [11-13].

In the present work, we report the determination by potentiometric method of the protonation constants of a series of reduced Schiff bases (Fig. 1) derived from ortho-phenylenediamine, and stability constants of their complexes with $\mathrm{Mn}$ (II), $\mathrm{Co}(\mathrm{II}), \mathrm{Ni}(\mathrm{II})$ and $\mathrm{Cu}(\mathrm{II})$ ions.

The aim of this study is the determination of both the effect of the $\mathrm{R}$ group and the reduction of the $\mathrm{C}=\mathrm{N}$ bonds on the stability of the complexes, by comparison of the results with those reported for Schiff base analogues.

\section{Experimental}

\subsection{Reagents}

ortho-Phenylenediamine, 3,4-diaminotoluene, 4chloro-1,2-phenylenediamine and salicylaldehyde were

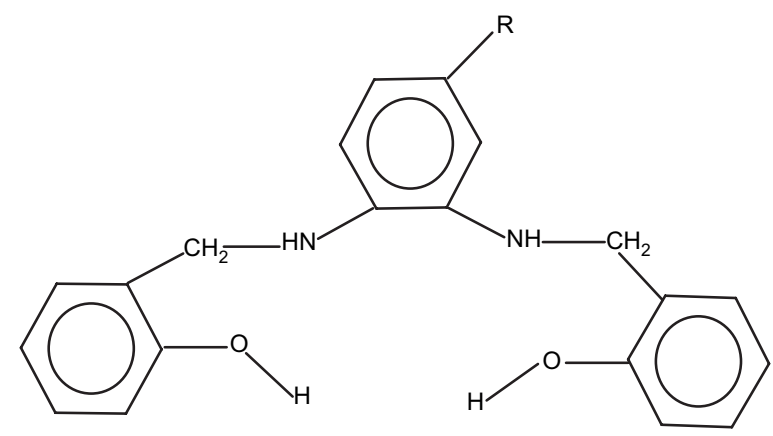

Fig. 1. Formula of ligands: $\mathrm{H}_{2} \mathrm{~L}^{1}: \mathrm{R}=\mathrm{H} ; \mathrm{H}_{2} \mathrm{~L}^{2}: \mathrm{R}=\mathrm{CH}_{3} ; \mathrm{H}_{2} \mathrm{~L}^{3}$ : $\mathrm{R}=\mathrm{Cl}$. purchased from Fluka and used without further purification.

Hexahydrated metal chlorides were obtained from Merck, exact concentrations of metal solutions were determined by titration with EDTA.

Carbonate-free sodium hydroxide used for the potentiometric titrations was prepared and standardized against a standard hydrochloric acid solution.

\subsection{Potentiometric measurements}

The potentiometric titrations were carried out in water-ethanol $(90: 10 \mathrm{v} / \mathrm{v})$ solution at a $0.2 \mathrm{~mol}^{-1}$ ionic strength $(\mathrm{NaCl})$ in a thermostated vessel at $25.0 \pm 0.1{ }^{\circ} \mathrm{C}$ under nitrogen atmosphere. The solutions were titrated with carbonate-free $\mathrm{NaOH}\left(0.1 \mathrm{~mol} \mathrm{l}^{-1}\right)$, the $\mathrm{pH}$ values were measured with a Hanna instruments HI 8417 pH meter.

The $\mathrm{pH}$ meter readings in water-ethanol $(90: 10 \mathrm{v} / \mathrm{v})$ mixture $\mathrm{pH}(\mathrm{r})$ differs by an amount from the corrected reading in aqueous medium $\mathrm{pH}^{*}$, according to the equation: $\mathrm{pH}^{*}=\mathrm{pH}(\mathrm{r})-\delta$ [14]. The value of $\delta$ for water-ethanol $(90: 10 \mathrm{v} / \mathrm{v})$ mixture was reported to be 0.02 . Accordingly, the presence of $10 \%$ of ethanol in the solvent has a minor influence on the protonation or the complexes' stability constants obtained.

The measurements were carried out for the ligand alone at the concentration $C_{\mathrm{L}}=5 \times 10^{-3} \mathrm{moll}^{-1}$, and for the ligand in the presence of metal cation (ligand/ metal ratio $1: 1$ ), at the concentration $C_{\mathrm{M}}=C_{\mathrm{L}}=$ $5 \times 10^{-4} \mathrm{moll}^{-1}$.

The Sirko program [15] was used to calculate both protonation and stability constants of the ligands and their complexes. Computer-refined values of the constants, corresponding to the minimum standard deviation were retained, and used for the calculation of species distribution.

\subsection{Synthesis of ligands}

The ligands were synthesized by reduction of Schiff base analogues by $\mathrm{NaBH}_{4}$ [16]. The Schiff bases have been prepared by refluxing in ethanol $2 \mathrm{mmol}$ of salicylaldehyde and $1 \mathrm{mmol}$ of ortho-phenylenediamine for $\mathrm{H}_{2} \mathrm{~L}^{1}$, 3,4-diaminotoluene for $\mathrm{H}_{2} \mathrm{~L}^{2}$, 4-chloro-1,2-penylenediamine for $\mathrm{H}_{2} \mathrm{~L}^{3}$. The resulting Schiff bases were recrystallized in ethanol, and then characterized by elemental analysis, NMR and IR.

In order to reduce the imine bonds, $1 \mathrm{mmol}$ of Schiff base was dissolved in absolute ethanol, and $3 \mathrm{mmol}$ of $\mathrm{NaBH}_{4}$ was added in small portions over $1 \mathrm{~h}$. The resulting mixture was stirred for $2 \mathrm{~h}$, during which 
time it changed color. Then, the solution was diluted and acidified with hydrochloric acid in order to destroy the excess of $\mathrm{NaBH}_{4}$.

The new ligand was extracted with $\mathrm{CH}_{2} \mathrm{Cl}_{2}$, the solvent was removed under vacuum and the resulting residue was washed with diethyl ether and stirred in hexane until it was transformed into a solid powder.

The elemental microanalyses were carried out at the Central Service of Analysis, CNRS Vernaison (France). The IR Spectra were recorded on a PerkinElmer spectrum one Fourier transform infrared spectrometer. ${ }^{1} \mathrm{H}$ NMR was recorded on a Jeol Gsx 270 MSB (270 $\mathrm{MHz}$ ) spectrometer.

\section{Results and discussion}

\subsection{Characterization of ligands}

Analytical data: found (calc.) for $\mathrm{H}_{2} \mathrm{~L}^{1}: \mathrm{C}, 75.32$ (75.00); H, 6.49 (6.25); N, 8.28 (8.75). For $\mathrm{H}_{2} \mathrm{~L}^{2}$ : C, 75.56 (75.44); H, 6.35 (6.58); N, 8.42 (8.38). For $\mathrm{H}_{2} \mathrm{~L}^{3}: \mathrm{C}, 67.56(67.70) ; \mathrm{H}, 5.49(5.35) ; \mathrm{N}, 7.45$ (7.89); $\mathrm{Cl}, 10.25$ (10.01).

The analysis of IR spectra of the ligands shows the absence of any strong absorption at $1615 \mathrm{~cm}^{-1}$ attributable to the imine bond, indicating the reduction of $\mathrm{C}=\mathrm{N}$ bond to the $\mathrm{C}-\mathrm{NH}$ one. This is confirmed by the presence of new absorption bands at $3390 \mathrm{~cm}^{-1}$ assigned to $\nu(\mathrm{N}-\mathrm{H})$ of the amino groups [17].

The IR spectra of the ligands exhibit broad medium intensity band in the $3200-3270 \mathrm{~cm}^{-1}$ range, which is assigned to the $\mathrm{O}-\mathrm{H}$ vibrations.

The aromatic rings give an intense band due to $\mathrm{C}-\mathrm{H}$ deformation at $700 \mathrm{~cm}^{-1}$.

The ${ }^{1} \mathrm{H}$ NMR spectra of the ligands (Table 1 ) have no azomethine hydrogen peaks at $8.2-8.5 \mathrm{ppm}$, but show

Table 1

${ }^{1} \mathrm{H}$ NMR spectral chemical shifts ( $\delta$ in ppm)

\begin{tabular}{lllll}
\hline Ligand & Aromatic protons & $\mathrm{CH}_{2}-\mathrm{N}$ & $\mathrm{CH}_{3}$ & $-\mathrm{OH}$ \\
\hline $\mathrm{H}_{2} \mathrm{~L}^{1}$ & $6.25-6.46(\mathrm{~m})$ & $4.30(\mathrm{~s})$ & & 11.25 \\
& $6.72-7.02(\mathrm{~m})$ & & & \\
& $6.89-7.08(\mathrm{~m})$ & & & \\
$\mathrm{H}_{2} \mathrm{~L}^{2}$ & $6.05-6.18(\mathrm{~m})$ & $4.30(\mathrm{~s})$ & $2.42(\mathrm{~s})$ & 11.08 \\
& $6.42-7.05(\mathrm{~m})$ & & & \\
& $6.45-7.02(\mathrm{~m})$ & & & \\
$\mathrm{H}_{2} \mathrm{~L}^{3}$ & $6.20-6.48(\mathrm{~m})$ & $4.30(\mathrm{~s})$ & & 11.10 \\
& $6.58-7.12(\mathrm{~m})$ & & & \\
& $6.45-7.06(\mathrm{~m})$ & & &
\end{tabular}

Measured as saturated solution in $\mathrm{CDCl}_{3}$, using TMS as the reference, $\mathrm{s}=$ singlet, $\mathrm{m}=$ multiplet .
Table 2

Protonation constants of the ligands $(\log K)$

\begin{tabular}{lrrr}
\hline Equilibrium & \multicolumn{1}{l}{$\log K$} & \\
\cline { 2 - 4 } & \multicolumn{1}{c}{$\mathrm{H}_{2} \mathrm{~L}^{1}$} & \multicolumn{1}{c}{$\mathrm{H}_{2} \mathrm{~L}^{2}$} & \multicolumn{1}{c}{$\mathrm{H}_{2} \mathrm{~L}^{3}$} \\
\hline $\mathrm{L}^{2-} / \mathrm{HL}^{-}$ & $11.30( \pm 0.04)$ & $12.32( \pm 0.03)$ & $10.88( \pm 0.08)$ \\
$\mathrm{HL}^{-} / \mathrm{H}_{2} \mathrm{~L}$ & $10.29( \pm 0.04)$ & $10.76( \pm 0.02)$ & $9.86( \pm 0.06)$ \\
$\mathrm{H}_{2} \mathrm{~L} / \mathrm{H}_{3} \mathrm{~L}^{+}$ & $5.12( \pm 0.01)$ & $6.02( \pm 0.04)$ & $4.30( \pm 0.07)$ \\
$\mathrm{H}_{2} \mathrm{~L} / \mathrm{H}_{3} \mathrm{~L}^{+}$ & $5.82( \pm 0.01)$ & $6.75( \pm 0.04)$ & $4.96( \pm 0.07)$ \\
\hline
\end{tabular}

Water-ethanol $(90: 10 \mathrm{v} / \mathrm{v}), I=0.2 \mathrm{M} \mathrm{NaCl}$.

new peaks at $4.2 \mathrm{ppm}$ attributable to the methylene groups. The amine hydrogen peak was not observed.

Nevertheless, these observations support the infrared data, and confirm the reduction of imine bonds to amine ones.

\subsection{Potentiometric measurements}

The constant $\beta_{p q r}$ calculated by the Sirko program are defined by the equilibrium:

$p \mathrm{M}^{2+}+q \mathrm{H}^{+}+r \mathrm{~L}^{2-} \rightleftarrows\left[\mathrm{M}_{p} \mathrm{H}_{q} \mathrm{~L}_{r}\right]^{(2 p+q-2 r)} \beta_{p q r}$

The successive constants $\log K$ for the ligands calculated from the overall constants $\log \beta_{p q r}$ are listed in Table 2.

The ligands are tetradentate with two adjacent weak amine donors and two strongly basic phenolate groups. Four constants were obtained for each ligand; the basicity sequence obtained is $\mathrm{H}_{2} \mathrm{~L}^{2}>\mathrm{H}_{2} \mathrm{~L}^{1}>\mathrm{H}_{2} \mathrm{~L}^{3}$.

The higher basic character of $\mathrm{H}_{2} \mathrm{~L}^{2}$ is attributable to the electron-donor effect of the methyl group; and the lower basic character of $\mathrm{H}_{2} \mathrm{~L}^{3}$ is due to the electronwithdrawing effect of the chloride atom.

Comparison of these results with those reported for Schiff base analogues [4-6] indicates that the protonation constants of these ligands are higher, especially

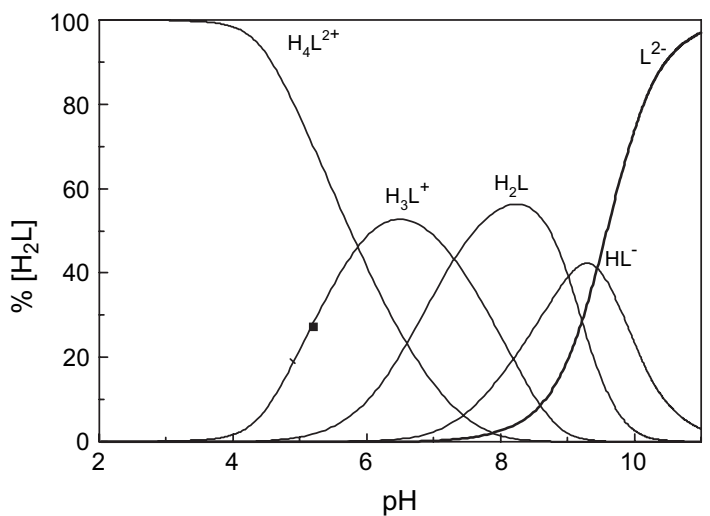

Fig. 2. Species distribution diagram of $\mathrm{H}_{2} \mathrm{~L}^{1}$. 
Table 3

Stability constants $(\log K)$ for the complexes

\begin{tabular}{|c|c|c|c|c|}
\hline Species & $\mathrm{Mn}$ & Co & $\mathrm{Ni}$ & $\mathrm{Cu}$ \\
\hline$\left[\mathrm{M}\left(\mathrm{HL}^{1}\right)\right]^{+}$ & $7.94( \pm 0.01)$ & $10.32( \pm 0.10)$ & $10.58( \pm 0.08)$ & $10.95( \pm 0.05)$ \\
\hline$\left[\mathrm{ML}^{1}\right]$ & $14.23( \pm 0.04)$ & $16.41( \pm 0.06)$ & $16.85( \pm 0.04)$ & $17.31( \pm 0.01)$ \\
\hline$\left[\mathrm{M}\left(\mathrm{HL}^{2}\right)\right]^{+}$ & $8.02( \pm 0.05)$ & $10.87( \pm 0.04)$ & $11.05( \pm 0.10)$ & $11.45( \pm 0.06)$ \\
\hline$\left[\mathrm{ML}^{2}\right]$ & $14.81( \pm 0.06)$ & $17.2( \pm 0.02)$ & $17.32( \pm 0.08)$ & $17.81( \pm 0.04)$ \\
\hline$\left[\mathrm{M}\left(\mathrm{HL}^{3}\right)\right]^{+}$ & $6.13( \pm 0.01)$ & $9.81( \pm 0.07)$ & $9.74( \pm 0.09)$ & $10.21( \pm 0.07)$ \\
\hline$\left[\mathrm{ML}^{3}\right]$ & $12.48( \pm 0.07)$ & $15.31( \pm 0.05)$ & $15.22( \pm 0.03)$ & $16.1( \pm 0.08)$ \\
\hline
\end{tabular}

Water-ethanol $(90: 10 \mathrm{v} / \mathrm{v}), I=0.2 \mathrm{M} \mathrm{NaCl}$.

those assigned to the nitrogen atoms of the amino groups. This arises because the nitrogen atoms of the Schiff base are not able to disperse charge to the solvent by hydrogen bonding [18].

The species distribution diagram as function of $\mathrm{pH}$ (Fig. 2) shows that the deprotonation of $\mathrm{H}_{4} \mathrm{~L}^{2+}$ occur at $\mathrm{pH}=4$ and leads to the successive formation of $\mathrm{H}_{3} \mathrm{~L}^{+}, \mathrm{H}_{2} \mathrm{~L}, \mathrm{HL}^{-}$and $\mathrm{L}^{2-}$, the deprotonation of both phenolic groups is completed at $\mathrm{pH}>10$.

Similar diagrams were obtained for $\mathrm{H}_{2} \mathrm{~L}^{2}$ and $\mathrm{H}_{2} \mathrm{~L}^{3}$.

The stability constants $(\log K)$ obtained for the complexes are listed in Table 3. For all the systems studied, only monomer species were formed, the model that best fits the experimental data is the one with formation of two species $[\mathrm{MHL}]^{+}$and $[\mathrm{ML}]$.

The $[\mathrm{MHL}]^{+}$species may be assumed to be protonated at the phenol oxygen of salicylaldehyde moiety. The complex [ML] results from the coordination of the metal to the ligand fully deprotonated. It is more stable than the complex $[\mathrm{MHL}]^{+}$, indicating that in the ML complex, the ligand is coordinated to the metal by both amino groups and phenolate oxygen atoms.

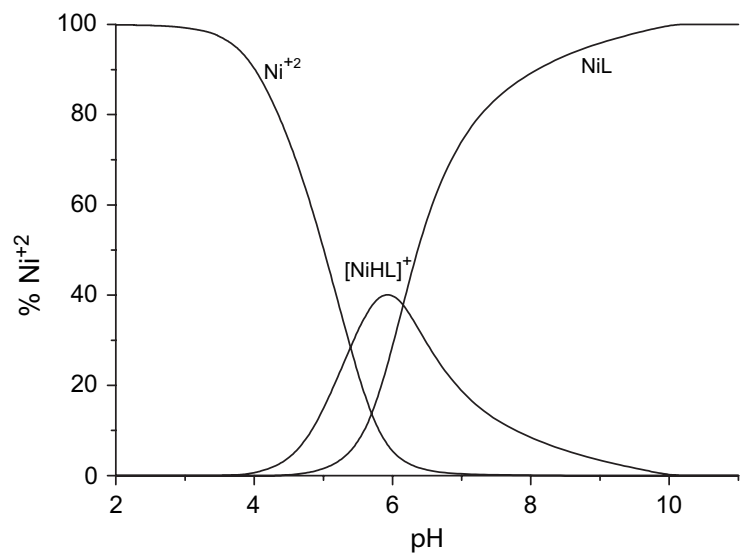

Fig. 3. Species distribution diagram of $\mathrm{Ni}-\mathrm{H}_{2} \mathrm{~L}^{3}$.
The systems $\mathrm{H}_{2} \mathrm{~L}^{2}-\mathrm{M}$ (II) $(\mathrm{M}(\mathrm{II})=\mathrm{Ni}, \mathrm{Cu}$, Co and $\mathrm{Mn})$ give complexes that are more stable than those for the systems $\mathrm{H}_{2} \mathrm{~L}^{1}-\mathrm{M}$ (II) due to the electron-donor effect of the methyl group, which is favorable to coordination.

For the systems $\mathrm{H}_{2} \mathrm{~L}^{3}-\mathrm{M}(\mathrm{II})$, the opposite effect applies and the stability of their complexes are less than those for $\mathrm{H}_{2} \mathrm{~L}^{1}-\mathrm{M}$ (II) systems, as a consequence of the electron-withdrawing effect of the chloride atom.

Thus, for any metal the stability sequence is $\mathrm{H}_{2} \mathrm{~L}^{2}>\mathrm{H}_{2} \mathrm{~L}^{1}>\mathrm{H}_{2} \mathrm{~L}^{3}$ in agreement with the basic character order of these ligands.

For the systems ML $\left(\mathrm{H}_{2} \mathrm{~L}=\mathrm{H}_{2} \mathrm{~L}^{1}, \mathrm{H}_{2} \mathrm{~L}^{2}, \mathrm{H}_{2} \mathrm{~L}^{3}\right)$, the stability sequence observed is $\mathrm{Cu}>\mathrm{Ni}>\mathrm{Co}>\mathrm{Mn}$, in agreement with Irving-Williams series.

The complexes of $\mathrm{Ni}(\mathrm{II})$ and $\mathrm{Co}(\mathrm{II})$ with these ligands are more stable than those reported with Schiff base analogues [4-6]. In fact, the complexes of reduced Schiff bases are expected to be more flexible as they are not constrained to be planar.

The species distribution diagram for $\mathrm{Ni}-\mathrm{H}_{2} \mathrm{~L}^{3}$ and $\mathrm{Cu}-\mathrm{H}_{2} \mathrm{~L}^{2}$ systems are reported in Figs. 3 and 4. Similar diagrams were obtained for the other systems.

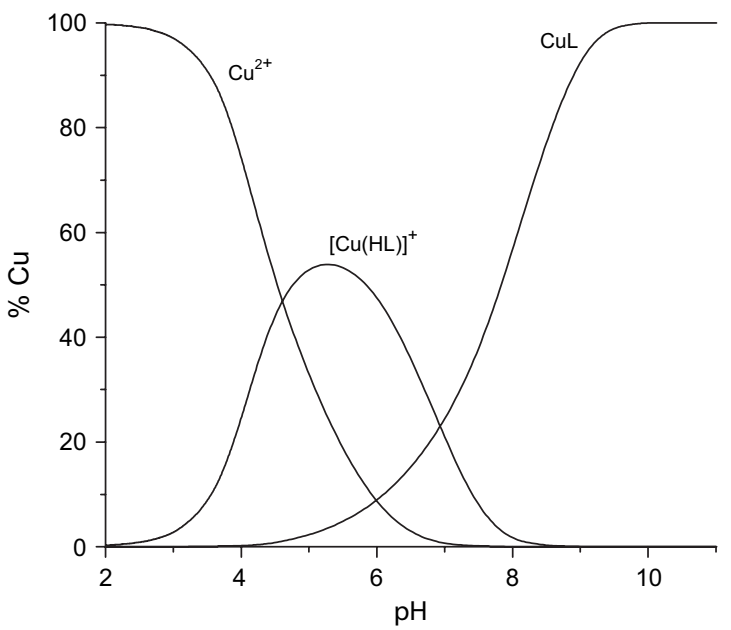

Fig. 4. Species distribution $\mathrm{Ni}-\mathrm{H}_{2} \mathrm{~L}^{3}$ diagram of $\mathrm{Cu}-\mathrm{H}_{2} \mathrm{~L}^{2}$. 


\section{References}

[1] J.A. McCleverty, T.J. Meyer, Comprehensive Coordination Chemistry II, From Biology to Nanotechnology, vol. 1, Elsevier, 2004, p. 411.

[2] D. Xu, B. Chen, K. Chen, K. Miki, N. Kasai, Bull. Chem. Soc. Jpn. 62 (1989) 275.

[3] P.H. Hang, J.G. Keck, E.T. Lien, J. Med. Chem. 33 (1990) 608.

[4] R. Hernandez-Molina, A. Mederos, P. Gili, S. Dominguez, P. Nunez, Polyhedron 16 (1997) 4191.

[5] R. Hernandez-Molina, A. Mederos, P. Gili, S. Dominguez, P. Nunez, G. Germain, T. Debaerdemaeker, Inorg. Chim. Acta 256 (1997) 319.

[6] A. Mederos, A. Medina, P. Gili, F.G. Manrique, P. Nunez, An. Quim. 82B (1986) 338.

[7] L.L. Koh, J.O. Randford, W.T. Robinson, J.O. Svensson, A.L. Chootan, D. Wu, Inorg. Chem. 35 (1996) 6466.

[8] V.K. Muppidi, P.S. Zacharias, S. Pal, Inorg. Chem. Commun. 8 (2005) 543.
[9] U. Casellato, S. Tamburini, P. Tomasin, P.A. Vigato, Inorg Chim. Acta 357 (2004) 4191.

[10] F. Lioret, J. Moratal, J. Faus, J. Chem. Soc., Dalton Trans. (1983) 1743.

[11] I.H. Hall, C.B. Lackey, T.D. Kistler, R.W. Durham, E.M. Jouad, M. Khan, X.D. Thanh, S. Djebbar-Sid, O. Benali-Baitich, G. Bouet, Pharmazie 55 (2000) 937.

[12] X.D. Thanh, S. Djebbar-Sid, O. Benali-Baitich, G. Pehu, M.A. Khan, G. Bouet, Anticancer Res. 20 (2000) 4639.

[13] X.D. Thanh, S. Djebbar-Sid, S. Duchene, O. Benali-Baitich, M.A. Khan, G. Bouet, Biol. Rhythm. Res. 32 (2001) 423.

[14] G. Douheret, Bull. Soc. Chim. Fr. (1967) 1412.

[15] V.I. Vetrogon, N.G. Lukyanenko, M.J. Schwing-Weill, F. Arnaud-Neu, Talanta 41 (1994) 2105.

[16] R. Bastida, A. de Bias, D.E. Fenton, C. Rial, T. Rodriguez, A. Sousa, J. Chem. Soc., Dalton Trans. (1993) 265.

[17] G. Socrates, Infrared Characteristic Group Frequencies, Wiley and Sons, 1980.

[18] A.E. Martell, R.D. Hancock, Metal Complexes in Aqueous Solutions, Plenum Press, New York, 1996, p. 54. 